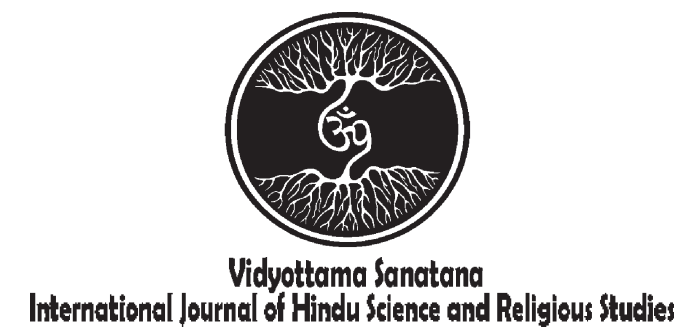

Vol. 1 No. 1 May 2017

\title{
Building Character And Literacy Skills Of Primary School Students Through Puppet Contemplative Sukuraga
}

\author{
By: \\ Iis Nurasiah, Din Azwar Uswatun, Arsyi Rizqia Amalia \\ Fakultas Keguruan \& Ilmu Pendidikan \\ Universitas Muhammadiyah Sukabumi \\ Jawa Barat, Indonesia \\ e-mail: $\underline{\text { salsabila arsa@yahoo.com }}$
}

\begin{tabular}{|l|l|l|} 
Received: September 12, 2016 & Accepted: May 22, 2017 & Published: May 31, 2017 \\
\hline
\end{tabular}

\begin{abstract}
Education is a process of enculturation, serves bequeath the values and achievements of the past to the future generations. Values and achievement that is the pride of the nation and the people make it known to other nations. In addition to bequeath, education also has a function to develop the cultural values and achievements of the past into the nation's cultural values corresponding to the life of the present and future, as well as developing new achievements into new character of the nation. Therefore, education, culture and national character is at the core of an educational process. literacy skills expected to provide supplies for children in reading, writing, and appreciating and responding to all types of communication. Creating literat generation requires a long process and means conducive. It begins with small and family environment, and are supported or developed in school, social environment, and the work environment. Puppet Sukuraga laden with enlightenment, education, reflection, invite people really keep up with both his body as a God-given mandate in accordance with the nature of their respective functions.
\end{abstract}

Keywords: Characters, Literacy Skills, Puppet Contemplative Sukuraga

\section{Introduction}

The issue of culture and national character has become the public spotlight. The spotlight on various aspects of life, embodied in a variety of posts in the print media, interviews, dialogues, and his speech in the electronic media. In addition to the mass media, community leaders, experts and observers educational, and social commentator talking about the issue of culture and national character in various seminars, both 
at the local, national, and international levels. Emerging problems in society such as corruption, violence, sex crimes, vandalism, fights mass, consumptive economic life, political kehidupn unproductive, and so become a hot topic of discussion in the media, seminars, and on various occasions. Various alternatives proposed settlement of such regulations, legislation, increased efforts to implement and apply the law stronger. The Ministry of National Education in early 2010 illustrates the need for a strong community education culture and national character. Moreover, if examined, that needs it, imperatively, is the quality of Indonesian human as outlined in the National Education Goals. Strengthening literacy skills expected to provide supplies for children in reading, writing, and appreciating and responding to all types of communication. This is in line with section 18 national character values are: friends / communicative, curiosity, and reading that are expected to support the successful creation of the character development (character building) golden generation of Indonesia

The creation process begins literat generation of small and family environment, and are supported or developed in school, social environment, and the work environment. Cultural literacy is also strongly related to the pattern of teaching in schools and the availability of reading materials in the library. According Naibaho (2007, pp. 3-4) is basically sensitivity and critical power will be an advantage as the environment surrounding the bridge toward literat generation, the generation that has the critical thinking skills to all the information in order to prevent emotional reactions. Culture is what seems to have not owned the majority of the Indonesian people. This is evidenced by the many events that take place in the midst of society which is based on communication errors, misunderstandings, and emotional outbursts moment. Indonesian society pitted against relatively easy, quick to act without trying to figure out a problem seated problems, quick to judge without knowing what the cause and akibatnya.Oleh therefore, see the exposure condition and their global challenges need to be faced by the students, especially elementary students, it is clear that the entire education stakeholders must have a comprehensive awareness of the compliance with the competence to compete in national and international arena. It is important to realize by an elementary school teacher in giving lessons to students.

Sukabumi, a small town in West Java that also has distinctive in culture, one of which is contemplative sukuraga. Wayang puppet is not the same as the puppet in Indoneasia other islands, such as shadow puppets, marionettes and puppets. Wayang puppet contemplative Sukuraga called because it has a distinctive raises the body in man. The form was in the form of hands, eyes, feet, mouth, ears and body parts lainnya. Melalui puppets coming from the area itself makes the heir to the nation's cultural capital, especially primary school students in the city of Sukabumi. The introduction of character education starts from a nearby neighborhood, namely themselves. Puppet Sukuraga educate elementary school students that we should keep our bodies to recognize the responsibilities and functions of the human body which will be accounted for at the end of life. In addition Puppet Sukuraga was developed into a comic children, batik painting and hand puppets that can be used as a medium of learning in school.

\section{Results and Discussion}

\subsection{Character Education}

Character refers to a much broader constellation of attitudes, behaviors, motivations, and skills. It is more than simply avoiding involvement in socially undesirable behaviors. Character includes attitudes such as the desire to do one's best and being concerned about the welfare of others; intellectual 
capacities such as critical thinking and moral reasoning; behaviors such as being honest and responsible, and standing up for moral principles in the face of injustice; interpersonal and emotional skills that enable us to interact effectively with others in a variety of circumstances; and the commitment to contribute to one's community and society. Stated simply, character is the realization of one's positive development as a person intellectually, socially, emotionally, and ethically. To be a person of good character is to be the best person that one can be (Victor Battistich, 2011:2).

Culture and National Character education requires changes in the implementation of the educational process that occurs in the school at the present time. The necessary changes do not change the applicable curriculum but require a new attitude and new skills of teachers, principals and school counselors. Attitudes and new skills is a requirement that must be met (conditio sine qua non) for the successful implementation of Education Culture and National Character. Changes in attitude and mastery of the skills required can only be developed through education in-service focused, sustained, and systemic.

Character as a 'moral excellence' or morality is built on various virtues (virtues) which in turn only has meaning when it is based on the values prevailing in the culture (nation). Indonesian national character is a character owned by a citizen of Indonesia based measures are considered as a virtue by the values prevailing in the society and the nation of Indonesia. Therefore, Culture and National Character Education focused on efforts to develop the values that underlie a virtue to become a citizen of personality. (Prof. Dr. H. Mansyur Ramly: 2010)

Different from teaching materials that are 'mastery', as well as a 'performance content' of a competence, materials and Cultural and National Character is 'developmental'.
Differences in the nature of both groups such material requires treatment differences in the educational process. Educational materials that are 'developmental' educational process requires quite a long and mutually strengthen (reinforce) the learning activities with other learning activities, between learning in the classroom with curricular activities at school and outside of school.

\subsection{Skills Literacy}

According to the UNESCO world education, the concept of literacy is no longer interpreted narrowly limited to the ability to read and write, but also related to the ability to make sense of the text, such as letters, numbers, and cultural symbols, such as images and symbols critically. According Wardi (2013, p 1) that literacy is an educational system that not only includes the ability to read and write but also involves interpret texts and cultural symbols.

Simply put, literacy can be defined as an ability to read and write. We knew with literacy or literacy. But now, literacy has a broad meaning, so that literacy is no longer a single meaningful but contains various meanings (multiple literacies). According to UNESCO, quoted by Nasution (2013, pp. 12-13), enter the six categories of the survival of the literacy skills of the 21 st century consists of:

1. Basic Literacy, sometimes called Functional Literacy (Functional Literacy), the basic capabilities of literacy or conventional learning systems such as how to read, write, and perform numerical calculations and operate so that each individual can function and have the opportunity to participate in society, in home, in the office or school.

2. Computer Literacy, a set of skills, attitudes and knowledge required to understand and operate the basic functions of information and communication technologies, including devices and equipment such as personal computers (PCs), laptops, cell phones, 
iPod, BlackBerry, and so forth, literacy computers are usually divided into hardware and software literacy.

3. Media Literacy, a set of skills, attitudes and knowledge required to understand and use different types of media and formats in which information is communicated from the sender to the recipient, such as images, sound, and video, and serves as a transaction between an individual, or as bulk transactions between a single sender and recipients, or, vice versa.

4. Distance Learning and E-Learning is a term that refers to the education and training modalities that use the network, in particular the World Wide Web and the Internet, as virtual classrooms instead of the physical classroom. In distance learning and e-learning, both teachers and students interact online, so students can complete the research and assignments from home, or anywhere where they can gain access to a computer and a telephone line.

5. Cultural Literacy. Aliteracy culture means knowledge, and understanding, of how a country, a religion, an ethnic group or a tribe, religion, symbols, celebrations, and how traditional communication, creation, storage, handling, communication, preservation and archiving of data, information and knowledge, using technology. An important element of understanding the information literacy is an awareness of how cultural factors impacting positively or negatively in terms of the use of modern information and communication technologies.

6. Information literacy is closely linked to learning for learning, and critical thinking, which is the goal of formal education, but often not integrated into the curriculum, syllabus and lesson plans, sometimes in some countries more often use the term information or information fluency competencies.
Meaning contained in the above explanation of literacy or literacy can be defined technological literacy, information literacy, critical thinking, sensitive to the environment, even sensitive to politics. A literat said if he can understand something by reading the right information and do something based on his understanding of the content of the reading. Sensitivity or literacy in a person certainly does not appear out of nowhere. No man who has been literat since birth.

\subsection{Puppet Sukuraga}

Ilham is a great gift that the Lord gave His servants who always followed the business always wandering in the search. Efendi wandering in search, looking for her identity in paintings almost twenty years, starting with his belief as stated in the scriptures that "the Lord will shut up man on the Day of Resurrection, and on that day the hands and feet talk show testimony time in the world", a sentence that gives great energy to the Efendi who finally found the form of his paintings. He began painting a stand-alone body, starting from the feet, hands, eyes and mouth.

In the body painting is not just painting the human body is mutilated into several bodies, but each body painted like talking, moving, on duty with their respective functions. Eg hand painting is not just drawing hand pieces, but drawing hands who spoke with his mouth and so on so anything with legs, mouth and so on. Lukisa body described by Efendi bagailan poetry rich symbols and very imaginative, he recalled brings us to the natural body is full of dynamics in running funsinya masing.Dari respective poetic painting that inspired Efendi develop into a puppet so that the story can be easier to be submitted to many people in a limitless number in the infinite well. Thus was born the puppet named Puppet Sukuraga.Wayang Sukuraga make sport as characters. 


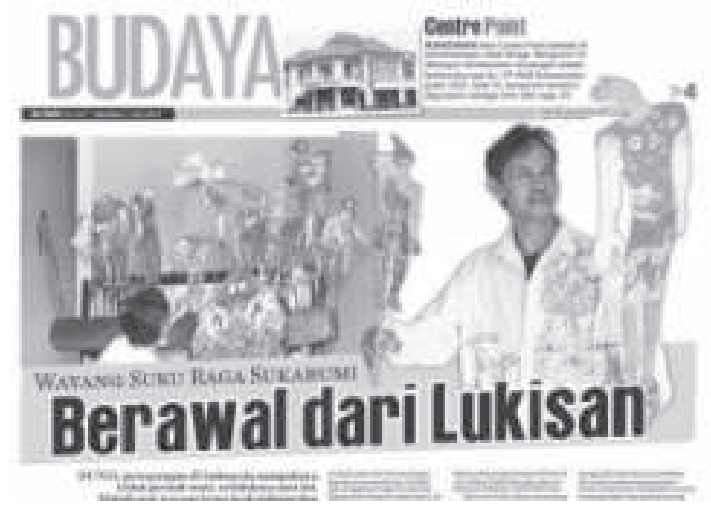

In creating the body as a puppet figure also with a clear concept, for instance when he made a hand puppet is a stand-alone hand like a man she had legs, arms, torso, legs shaped head, so the puppet's eyes, ears and seterusnya.Sehingga puppet figure of each each of these bodies is very strong, not just a puppet with rag-body mutilation.

From the results of the contemplation of a painter, the art has donated a work of performance called Wayang Sukuraga laden with enlightenment, education, reflection, invite people really keep up with both his body as a mandate given by God in accordance with the nature of their respective functions (Asrizal Nur :2010).

Inculcate - as a creative attitude to the character education of children, in the era of the digital era as it is today in need and not easily .apalagi along with its rapid development of information technology through the internet with android devices continues to grow, the impact is not only children who always wanted to Instant.

Efendi Sukuraga always mamanfaatkan time anytime anywhere when you meet groups of children always storytelling puppet sukuraga, Efendi Sukuraga participate in its mission to educate children of the nation do not count the time while showcasing puppet Sukuraga to the accompaniment of his puppets nayaga group. alone any musical instruments or without tools musik..Efendi Sukuraga keep doing storytelling

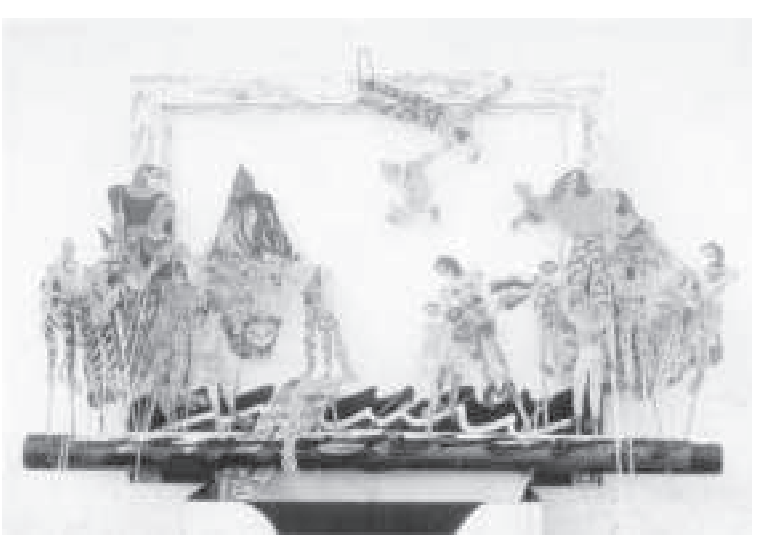

or puppet tells about sukuraga .Since October 2014, fendi also did, beating his own musical instrument which should be in percussion by 4 now he's done, the equipment in is a traditional percussion instruments such as drums, gamelan, bonang and manacle, choose a tool trdisional so that children, especially the younger generation to love and be able to play traditional music .Before storytelling Efendi always motivate children through the game - he created his own games or so now Fendi Sukuraga always ready for the call of the invitation as a motivator by means sukuraga puppet storytelling, play music and games or other creative. Mayor of Sukabumi, certifies Puppet Sukuraga into art distinctive culture of the city starting from February 12, 2016. (kompas.com:2016). Sukuraga puppet art can add to the distinctive culture of the city of Sukabumi well as community pride.

\section{Conclusion}

The Ministry of National Education in early 2010 illustrates the need for a strong community education culture and national character. Moreover, if examined, that needs it, imperatively, is the quality of Indonesian human as outlined in the National Education Goals. Strengthening literacy skills expected to provide supplies for children in reading, writing, and appreciating and responding to all types of communication. This is in line with section 18 the value of the nation's character, namely: 
friends / communicative, curiosity, and reading that are expected to support the successful creation of the character development (character building) golden generation of Indonesian Art is the inspiration given by God to man as a token of appreciation of self. Puppet Sukuraga which is the result of inspiration Efendi can be used as a medium of education literisai characters. Wayang unique shape facilitates the transfer of knowledge will be full of educational karakter.Siswa easily remember the puppet characters and narratives that are full of meaning, and students are easy to imitate and mengapikasikan in his life, not only the cognitive ability to be obtained but affective and psychomotor abilities of students will honed. Cognitive intelligence, emotional intelligence and spiritual intelligence will increase.

\section{References}

Anonim. (2016). [Artikel]. https//: www.facebook.com/asrizal-nur/wayangkontemplatif-b...:Maret 2016
Berkowitz, M. W. (2000). Character education as prevention (pp. 37-45). In W. B. Hansen, S. M. Giles, and M. D. FearnowKenney (Eds.), Improving prevention effectiveness. Greensboro, NC: Tanglewood Research.

Development of Culture and National Character Education Ministry of National Education, the National Research and Development of Curriculum Center, Jakarta: 2010.

Host Dholina testifying, Proceedings of the National Seminar on Primary Education Building Imagination And Creativity Children Through Literacy, Sps Upi 2015.

Victor Battistich. (2011). Character Education, Prevention, and Positive Youth Development. [Artikel]. Diunduh dari: httpwww.character.orgwpcontentuploads201112White_ Paper_Battistich.pdf. 